\title{
The Effect of Reward Management on Employees Commitment in the Universities in Nakuru County-Kenya
}

\author{
Isaack Korir, Dinah Kipkebut \\ Department of Business Administration, Egerton University, Nakuru, Kenya
}

Email address:

izongasu@gmail.com (I. Korir), jerutodiana@gmail.com (D. Kipkebut)

To cite this article:

Isaack Korir, Dinah Kipkebut. The Effect of Reward Management on Employees Commitment in the Universities in Nakuru County-Kenya. Journal of Human Resource Management. Vol. 4, No. 4, 2016, pp. 37-48. doi: 10.11648/j.jhrm.20160404.12

Received: April 4, 2016; Accepted: April 18, 2016; Published: August 21, 2016

\begin{abstract}
The aim of this study is to examine the effect of financial and non-financial rewards on organisational commitment of employees in Universities in Nakuru County. The specific objectives of the study were as follows: to determine the effect of financial reward on normative commitment of employees in universities in Nakuru County; to determine the effect of financial rewards on affective commitment of employees in universities in Nakuru County; to establish the effect of financial rewards on continuance commitment of employees in universities in Nakuru County; and finally, to determine the combined effect of rewards management on employees organisational commitment in universities in Nakuru County. The sample size of the study comprised 224 full-time lecturers working in 10 universities within Nakuru County. Data was collected using the questionnaire method. The data obtained was processed using the Statistical Package for Social Sciences (SPSS) and was analysed using both descriptive and inferential statistics. The analysed data was presented using graphs, charts and tables. Results indicated that there was a moderate significant positive relationship between financial rewards and affective commitment $(\mathrm{r}=0.344, \mathrm{p}<0.000)$ and a weak significant positive relationship between financial rewards and normative commitment $(r=0.249, p<0.008)$. The study found that financial reward management practices collectively have significant effect on organizational commitment. The study recommended that universities in Nakuru County should carry out salaries reviews in order to develop a reward management structure that is externally competitive, internally fair and consistent with the current acceptable international rates. It was also recommended that the top management in the Universities should encourage employees' to participate in decision making and they should implement employee decision.
\end{abstract}

Keywords: Financial Reward Management, Employees' Commitment, Teaching Staff

\section{Introduction}

Rewards management has gained increased importance especially in the current dynamic and competitive environment. This is because it enables organizations to recruit and maintain employees as well as to increase organizational productivity (Dalvi and Ibrahim, 2013). Datta (2012) argues that many organizations consider employees as their main factor in creating organizational value and competitive advantage. As a result, it is important to maintain employees, create motivation and increase job productivity through diverse strategies like rewards. Therefore, it is necessary for companies to design reward systems based on employees' skills and capabilities as well as in accordance with the organizational goals so as to improve performance and motivation.
According to Armstrong and Murlis (2007), Reward management refers to the strategies, policies and processes that are required to ensure that the contribution of people in an organization is recognized by both non-financial and financial means. There are two categories of reward; financial rewards, tangible and they relate to pay as well as the benefits that an organization provides to its employees and non-financial rewards; rewards which focus on motivating employee as well as enhancing job engagement and commitment. Reward management in an organization is one of the most indispensible elements in motivating employees to contribute their best effort in order to generate innovative ideas that lead to better business operations. This implies that the aim of rewards management is to develop and operate rewards systems which lead to improved employee motivation and organizational commitment. 
Armstrong (2012) argues that when rewards are well managed, desired commitment are achieved efficiently and effectively since the employees get a sense of mutual gain. This gain is always interterm with the organization as well as with the employee in the attainment of the defined target or goals. White and Druker (2013) emphasize that reward management systems are meant to complement and reinforce business strategies.

Armstrong et al (2009) state that reward management in high performing organizations are designed in ways that make them to have accurate predictions on their current and future expected results. This is because total rewards management concept emphasizes on the need to reward employees so as to obtain satisfaction in their work. Armstrong and Baron (2005) noted that obtaining employee satisfaction through total rewards strategy enables an organization to accurately predict its present and future performance thereby enabling it to plan its operations more effectively. According to Molahosseini et al (2014), behaviour of employees in all organizational levels is affected by the behaviour of managers which is derived from their power to use resources. Therefore, managers can use rewards so as to motivate the behaviour of employees and thereby attain the required organizational results.

Jiang et al (2009) note that rewards management strategies are used to manage transformation in organizations. This is because rewards management policies do not only reflect and acknowledge what employees have contributed in an organization but they also indicate a company's strategic objectives and values. Ghorbani and Ladoni (2013) emphasize that rewards systems encourage employees' efforts and they indicate the values and ideals of an organization. According to Molahosseini et al (2014), reward management systems should be designed in a way that ensures maximum benefits for an organization. This requires rewards to be designed in a way that leads to effective organizational performance. Dalvi and Ebrahimi (2013) observe that rewards can be an effective mechanism for encouraging employees and creating innovation as well as motivation. This can in turn lead to organizational transformation through knowledge sharing.

According to Dalvi and Ebrahimi (2013), a well-designed reward system creates a sense of belonging among employees in an organization. It enhances employee growth and development, and increases employee self-esteem and this leads to healthier organizations. Thus, organizational development is based on continued employees' motivation and this can be achieved through total rewards management strategy. Jiang et al (2009) argues that rewards management systems influence the efficiency of an organization and it also helps it to achieve its goals by increasing motivation and commitment. Danish (2010) emphasizes that effective reward management leads to increased employee motivation and this may in turn enhance employee commitment.

Ihionkhan and Aigbomian (2014) observe that organizations need effectively and efficiently committed employees in order to enable them to achieve their objectives. Affectively committed employees have a sense of identification and belonging with an organization and this increases their involvement in the activities of an organization (Rhoades et al, 2001). According to Danish (2010), motivation depends on certain intrinsic and extrinsic factors which when combined lead to employees who are fully committed. This can in turn lead to increased organizational performance as well as to encourage employee innovations and to encourage them to support the goals of the organization.

According to Dubihlela and Rundora (2014), the increased global competition has forced businesses to ensure increased employee commitment in order to enable them to have high levels of excellence and competitiveness in their processes. This is because committed employees have a desire and willingness to pursue the objectives of an organization thereby making the business to excel. Ihionkhan and Aigbomian (2014) argue that reward management strategies can be used to increase employee commitment by creating a sense of belonging in the organization. This means that organizations can increase the level of employees' commitment by ensuring effective reward management strategies. Therefore, organizations should take actions so as to obtain employee commitment through total reward management. In this regard, a study on the effects of rewards management on employee commitment can be valuable.

\subsection{Statement of the Problem}

In the world today, most universities have suffered the consequences of poor performance, low staff morale and high employee turnover due to poor or lack of effective reward management programs (Kirunda, 2010).A critical look at Universities in Kenya and in particular Nakuru County, reward management is a factor that needs to be looked into. This is necesitated by the various murmurs, go slows and strikes that occurs occassionally owing to unequal remuneration packages compared to relevant others.A good number of these Universities have poor or no reward management structure that offently result to uncommited employees. The aim of rewards management is to ensure that the value of employees and the contributions that they make in an organization is recognized and rewarded (Armstrong, 2012). This means that organizations use rewards management in order to fulfil and satisfy the needs of their employees as well as to ensure that they operate equitably and fairly. Danish and Usman (2010) point out that those employees are fully motivated and satisfied with their jobs when their needs are met and this may lead to increased organizational performance and commitment. This implies that employees' performance and commitment is based on the ability of an organization to recognize and reward its employees in respect to their input. Nonetheless, although many studies have focused on the effects of rewards management on employees' performance, only a few have focused on the effects of rewards management on employees' commitment (Joo, 2010; Lamasro, 1999; Nwosi et al, 2013). Therefore, it is evident that there is a knowledge gap to be 
filled. Therefore, the purpose of this study is to fill this gap by determining the effect of reward management on employee commitment in universities in Nakuru County.

\subsection{Objective of the Study}

i. To determine the effect of financial rewards on affective commitment of employees in universities in Nakuru County.

ii. To determine the effect of financial rewards on normative commitment of employees in universities in Nakuru.

iii. To determine the effect of financial rewards on continuance commitment of employees in universities in Nakuru County.

\subsection{Hypotheses of the Study}

$\mathrm{HO}_{1}$ : Financial rewards do not have a significant effect on affective commitment of employees in universities in Nakuru County.

$\mathrm{HO}_{2}$ : Financial rewards do not have a significant effect on normative commitment of employees in universities in Nakuru County.

$\mathrm{HO}_{3}$ : Financial rewards do not have a significant effect on continuance commitment of employees in universities in Nakuru County.

\section{Literature Review}

\subsection{Rewards Management}

Reward management refers to the strategies, policies and processes that are required to ensure that the contribution of people in an organization is recognized by both non-financial and financial means (Armstrong, 2007). This implies that rewards management encompasses the design, implementation and maintenance of reward systems which target both the organization and its stakeholders. According to Karami et al., (2012), a reward system should be effective and efficient in order to enable an organization achieve its goals and it should be designed in a way that creates maximum returns to both the corporation and its employees. Therefore, reward management is concerned with ensuring that people in the organization are rewarded equitably, fairly and consistently so as to ensure the achievement of organization goals.

Armstrong (2007) notes that rewards management does not only involve employee pay and benefits but is also concerned with non-financial rewards such as learning and development, recognition, praise and increased job responsibility. Njanja et al., (2013) emphasizes that recognition and appreciation are other integral components of rewards management. According to Karami et al. (2012), maintaining attention to the main needs of employees and ensuring fair distribution of rewards both inside and outside the organization are the main ideologies in any reward system. Carnellus (2001) observes that reward management is important because it contributes to the achievement of corporate goals. Consequently, the reward management strategy of a company should be designed in a way that it attracts and retains the right employees by ensuring that there is a direct relationship between rewards and efforts.

According to Armstrong (2012), the aim of reward management is to ensure that business goals are supported and achieved by developing and stimulating a culture of performance. Karami et al. (2013) notes that appropriate timely and effective reward enhances employees' motivation which in turn leads to improved commitment as well as achievement of organizational goals. Wang and Feng (2003) observe that reward management is one of the most important and significant variable influencing organizational ethics and job performance. This is because it directs the general attitudes of an employee to the job. Heneman (2013) points out that the objective of reward management in an organization is to align reward practices in line with the needs of employees. To Armstrong (2012), reward management is based on the principles about what the organization wants to achieve. Therefore, an organization must align its reward practices with both the employee needs and the goals of the business in order to achieve its objectives. According to the Chartered Institute of Personnel Development (2007), alignment of reward management practices with personnel needs creates employee satisfaction which leads to higher productivity. This in turn assists the organization towards achieving its goals.

Fransson and Frendberg (2008) points out that reward management attract and retain high quality employees. This means that for an organization to attract and retain talented employees, it must offer attractive and appropriate rewards. The Centre for Effective Organizations (2008), observes that the ability of an organization to attract and retain employees depends mostly on its rewards. This is due to the fact that good rewards lead to high level of employee satisfaction which in turn leads to low turnover. Armstrong (2012) observes that employees are satisfied with their jobs in organizations that provide competitive rewards and this makes them to want to stay in the same organizations thereby leading to high levels of employee retention.

Armstrong (2012) further reports that reward management aims at defining the right behaviors and outcomes by outlining expectations through contingent pay schemes and performance management. Similarly, Manas and Graham (2003) emphasize that rewards can be used to drive the right behaviours and outcomes in an organization. This means that reward systems can be used to motivate employees' performance by making them to choose behaviors that lead to outcomes that satisfy their objectives. The Centre for Effective Organizations (2008) notes that, every employee behaviour is associated with certain outcomes related with rewards and punishments. This implies that employees perceive that each performance level can lead to better rewards. Therefore, employees are motivated to adopt the right form of behaviour with the belief that performance will lead to better rewards.

Gilmore and Williams (2012) report that organizations should use the reward management function of reward people 
according to the value that they create in the organization by providing rewards which are in line with the degree by which they meet expectations. According to Armstrong, Brown and Reilly (2010), reward management is concerned with the processes of developing, implementing, operating and evaluating reward policies and practices that recognize and value people according to the efforts and contributions they make towards achieving organizational, departmental and team goals. Therefore, reward management should serves as a means of motivating employees. Employee rewards may be looked at as total reward which refers to the compensation which an employee receives from an organization for rendering his or her services (Jiang et al, 2009). It includes all the financial and non-financial benefits that are given by an organization to its employees. Karami et al (2013) emphasizes that total reward does not only encompass the financial benefits that are given to an employee benefits, but also includes non-financial rewards.

\subsubsection{Base Pay}

Base pay refers to the level of pay upon which the rate for the job is established (Armstrong, 2012). It is the least amount of remuneration that an employee in a given position can receive. Martin (2010) emphasizes that base pay is the salary that an employee receives and it does not include incentive benefits and pay. Ashield, (2007) observes that the base pay may be used to provide a platform for determining additional payments associated with competence, skills and performance. Additionally, the base pay may be used to determine an employee's life insurance and pension entitlement. According to Jackson et al., (2008), base pay is predictable and fixed. This means that employees are guaranteed that they will receive their base pay provided that they report to work and perform within the acceptable levels. Armstrong (2012) observes that base pay may be arrived at through negotiation or by assessing the existing market rates. Nonetheless, an organization should constantly adjust the base rate in order to reflect increases in the market rates and in the cost of living (Martin, 2010).

\subsubsection{Contingent Pay}

Contingency pay refers to any form of financial reward that is paid in cash as a bonus or added to the base rate and $\mathrm{s}$ linked to an employee's performance, skills, competence and contributions to the organization (Armstrong and Murllins, 2007). According to Njanja et al., (2013), organizations use contingency pay in order to reward their employees for meeting and exceeding the set targets. The amount of contingency pay is determined based on the level of performance or on the employee rank in the organization. Additionally, it can be based on career development, competence as well as on the level of skills of the individual employees (Armstrong, 2012). Bryson et al., (2013) notes that contingent pay schemes have become essential components of human resource policies all over the world. This is because they perform an important role in ensuring that organizations become more effective in achieving their goals. Njanja et al., (2013) observes that employees who receive large bonuses are likely to improve their commitment in order to receive more bonuses. Thus, contingency pay acts as a means of motivating employees and this enables an organization to achieve its objectives. Armstrong and Mullis (2007) emphasize that contingent pay is regarded as the best method of motivating people in an organization.

Shield (2007) argues that contingency pay provides a means through which an organization can define and set the levels of expectations and performance. This is because of the facts that pay acts as an incentive that can be used to encourage and support the desired behaviors in an organization. However, Armstrong and Mullis (2007) note that contingent pay schemes can create more dissatisfaction in an organization if employees perceive them as badly managed, inadequate and unfair. Contingent pay schemes rely on the judgment of managers in the absence of reliable and accurate methods of measuring employee performance and competences. Therefore, they can be biased and inconsistent thereby de-motivating employees.

\subsubsection{Employee Benefits}

According to Martin (2010), employee benefits are the range of additional rewards that are provided to employees by an employer as part of their total remuneration package. They are indirect payments made to an employee and they include insurance cover, pensions, company cars, annual holidays and sick pay. Armstrong (2012) emphasizes that employee benefits consist of elements of remuneration which are added to the different forms of cash pay. The benefits contribute to the security as well as the overall quality of an employee life.

Gracci and Kleiner (2006) note that benefits are offered to discourage job-hopping by providing employees with an appealing working environment. Additionally, employee benefits provide a means through which employers can attract talented employees. This is because the benefits provided by an employer have a significant impact in influencing the choice of an employee. Hong et al., (2005) emphasizes that most employees are attracted to work in places where workers are provided with important benefits. Therefore, employee benefits play an important role in the development of an organization and in improving corporate industrial relations.

\subsection{Organizational Commitment}

Dockel (2003) outlined a number of definitions to commitment as put forward by various authors. Salancik (1977) defined commitment as a state of being where an individual is bound by his/her actions to sustain activities in which he/she is involved. Scholl (1981) defined commitment as an internal force that maintains behavioural conditions when equity conditions are unmet while Oliver (1990) considers commitment as one's inclination to act in a given way to achieve a given target. According to Mowday et al. (1979) cited by Price (2011), organizational commitment refers to the degree of involvement and identification that employees have with their organization values, mission and 
goals. This means that employee commitment is the desire that employees have to stay in an organization by having confidence with its values and objectives. Armstrong (2012) emphasizes that employee commitment is the loyalty and attachment that employees have in an organization and it is associated with their feelings about the institution. Therefore, commitment signifies both the behavioural tendencies and the feelings that employees have towards an organization.

Lee (2010) observes that employee commitment involves an employee's devotion and the willingness to exert effort on behalf of an organization. This implies that employee commitment is an emotional state that exemplifies employees' relationships with an organization and the choice to stay in the organization. Porter et al., (1974) cited by Armstrong (2012) point out that organizational commitment is the linkage between an organization and the individual employees. This is because employees consider the extent to which organizational goals and values relate to their own. According to Oreilly and Chatman (1986) cited by Dockel (2003), organizational commitment can be categorized into; compliance which is concerned with involvement for certain extrinsic needs, identification concerned with attachment based on desire for affiliation with the organization and internalization commitment that is based on congruence between the individual and organizational needs. Allen and Meyer (1990), cited by Price (2011) on the other hand proposed three components of commitment; affective commitment concerned with emotional attachment with the organization, continuance commitment concerned with fear of costs associated with leaving the organization and normative commitment based on a feeling of obligation to continue employment. In this study, affective, continuance and normative components will be considered as dimensions of organisational commitment.

\subsubsection{Affective Commitment}

Affective commitment refers to the emotional attachment that an employee has in an organization (Price, 2011). It is the extent at which employees appreciate to be members of an organization. According to Rhoades (2001), affectively committed employees are seen to have a sense of identification and belonging and this motivates them to increase their participation in the activities of an organization. Additionally, affective commitment makes employees to have willingness to meet the goals of an organization as well as the desire to stay in the organization. Beck and Wilson (2000) note that organizational members who have an affective level of commitment have a longing to remain in the organization because they view their values and goals to be congruent with those of the organization.

Morrow (1993), cited by Coetzee, (2005) points out that affective commitment is related with work attitude and positive feelings about their organization. The work attitude is related with how employees view the organization and this attaches them to the institution. According to Meyer and Allen (1997), cited by Lee (2010) affective commitment is associated with employee personal characteristics, organizational features, experiences about the work and job characteristics. Muncherji and Dhar (2011) observe that employees become emotionally attached to an organization when they are able to achieve these factors. This is because they help to create an environment that is intrinsically rewarding for the employees.

In many organizations, the antecedents of affective commitment come under four distinct categories namely: personal characteristics, structural characteristics, job-related characteristics and work experience, (Mowday,1982).It is with such a motivation that the employee who posses strong affective commitment will continue to work for the organization because they want to do so. According to Meyer \& Allen (1997) employees with strong affective commitment would be motivated to high levels of performance and make more meaningful contributions than employees who expressed continuance and normative commitment. This happens owing to the fact that the employee identifies and associate himself/herself with every aspect of the organization.

\subsubsection{Continuance Commitment}

Meyer and Allen (1997), cited by Lee (2010) define continuance commitment as the employee awareness of the costs that are related with departing the organization. This means that continuance commitment is the enthusiasm to remain in an organization due to the personal investments which cannot be transferred. Price (2011) argues that continuance commitment exists when an employee needs the benefits and the salary associated with remaining in an organization. Additionally, it may arise when employees feel that they cannot find another job or when they believe that they owe their success to the organization.

According to Coetzee (2005), continuance commitment is calculative in nature because it is based on an employee opinion by weighing the risks and costs associated with leaving an organization. It is centered on an evaluation of the economic benefits gained by being associated with the organization. Beck and Wilson (2000) note that organizational members develop continuance commitment due to the positive extrinsic rewards that they have obtained through the exertion of bargaining without identifying with the values and goals of the organization. Therefore, employees are lured to remain in an organization due to the accumulated investments that they have gained in the organization.

\subsubsection{Normative Commitment}

According to Meyer and Allen (1997), cited by Lee (2010) normative commitment is a feeling of obligation that an individual has to continue with the employment. It arises from an employee obligations and personal values that the person feels towards the organization. Coetzee (2005) emphasizes that employees' with a high level of normative commitment feel that they ought to remain with the organization. The feeling of obligation to stay in the organization may come about due to the internalization of normative pressures exercised on an employee before joining 
the organization (Muncherji and Dhar, 2011).

Price (2011) observes that normative commitment may arise when employees are provided with rewards in advance by an organization. This may in turn make the employees to feel obliged to reciprocate thereby committing themselves to the organization. Meyer and Allen (1990) cited by Coetzee, (2005) argue that normative commitment arises based on an employee's moral obligations. This implies that individuals consider it as morally right to remain in an organization irrespective of whether they are satisfied with their jobs or not. Therefore, normative commitment emerges as a result of employees feelings to repay the organization for investing in them. These type employees remain in the organization because they need to so.

\subsection{Theoretical Review}

Singh (2007) states that rewards management has an element of behavioural objective that aims to fulfil a need and motivate employees in order to achieve the goals of an organization. Consequently, there are a number of theories that exist in the area of rewards management. These theories try to explain the role of rewards management in motivating employees so as to increase performance.

\subsubsection{The Herzberg Two-Factor Theory}

The two-factor theory divides job-related aspects into motivators and hygiene factors (Jiang et al., 2009). Hygiene factors consist of elements that are extrinsic in value and they include compensation and employee benefits. Narsee (2012) points out that hygienic factors include company policies, quality of supervision, employees and human relations, personal life, pay rate and job security and working conditions. On the other hand, motivators are factors that are intrinsic in nature and they include praise and recognition. They include achievement, career development, personal growth, job interest, recognition and responsibility. According to Singh (2007), total rewards can be used to meet employees' needs in terms of hygiene factors and motivators thereby increasing their motivation.

According to Narsee (2012) there are three possible scenarios that may occur; dissatisfaction and demotivation, no satisfaction and no motivation and positive satisfaction and motivation. Hygienic factors are vital component of the job itself as they determine the level of accomplishment and appreciation one attaches to the job. Organizations must therefore focus on developing tasks that are involving, engaging and fulfilling if the employees are to be motivated at work.

\subsubsection{Social Exchange Theory}

Social exchange theory is considered one of the most influential paradigms in organizational behaviour. The exchange perspective views the employment relationship as consisting of social or economic exchanges (Aryee, Budhwar and Chen, 2002; Cropanzano, Rupp and Bryne, 2003). Economic exchange relationships involve the exchange of relatively concrete, often economic benefits that are exchanged for work performance (Haar, 2006). On the other hand, social exchange theory argues that employees will trade their efforts for the promise of rewards in the future (Blau, 1964).

Social exchange theory is based on five central elements. The first element is that behaviour is predicted by the notion of rationality; individuals will behave in a given way if they believe behaving in that way will give more rewards. The second element is that the each individual relationship provides benefit to the other so long as the exchange is equitable. The third element is that the theory is based on a justice principle; for every exchange, there must be fairness governing behaviour. The next element of the theory is that individuals will always seek to maximize gains and reduce costs and losses. The last element is that individuals participate in a relationship out of a sense of mutual benefit rather than coercion (Searle, 1990).

Social exchange theory therefore suggests that employees who value benefits received from their organization, such as pay, fringe benefits or working conditions, will reciprocate with more positive work attitudes. The theory posits that individuals form social exchange relationships to the extent that they receive worthwhile benefits and that these benefits are assigned in a fair manner (Cropanzano et al., 2001; Haar, 2006). Therefore, employees perceiving negative and distressing workplace conditions are likely to reciprocate with negative work attitudes while those perceiving the workplace conditions as positive and challenging will reciprocate with positive work attitudes. It is therefore, expected that employees who are dissatisfied with their financial and non-financial rewards are likely to reciprocate with negative work attitudes such job dissatisfaction, low morale and reduced organizational commitment, while those who perceive their rewards as satisfactory are likely to reciprocate with positive work attitudes, such as high commitment, job satisfaction and low turnover (Cropanzano et al.,., 2003; Crede et al.,., 2007). In inducements the organization summary, therefore, the exchange theory posits that employees who are satisfied with the rewards and offers are likely to have higher job performance, organizational commitment and weaker turnover intentions.

\subsection{Empirical Studies}

Danish and Usman (2010) in a study to determine the impact of reward and recognition on job satisfaction and motivation of employees from both private and public sectors organizations in Pakistan found that rewards and recognition were positively related with motivation. They concluded that effective rewards management leads to increased employee motivation and commitment. These findings are similar to the findings of Ghorbani and Ladoni (2013), who conducted a study of 84 production managers, marketing managers and senior managers from home appliances companies in Iran to establish the effect of reward systems mechanisms on new product development. The results of their study indicated that there was a positive and a statistical significant relationship between rewards management and new product development. 
They concluded that managers can influence new product development by collectively developing, implementing and designing effective reward systems.Janja et al., ., (2013) in a study of 84 employees of Kenya Power and Lighting Company (KPLC) in Nakuru examined the effect of reward on employee performance. The results of the study indicated that financial rewards had no significant effect on employee performance. The study concluded that organizations should seek to understand their employees' needs so that they can employ the right motivational strategies.

Dalvi and Ebrahimi (2013) studied the effects of reward on the cooperation in sales and marketing department among 180 managers' from Isfahan food industries in Iran. The results of their study showed that organizational rewards had a weak effect on employees' motivation in the sales and marketing department. They concluded that organizations should design their rewards systems based on an employee's expertise, efforts and performance in order to reduce conflicts in organizations. Additionally, they suggested that rewards systems should be designed according to the needs of employees. Roberts (2005) in a study of the relationship between rewards, recognition and motivation of 1373 employees of an insurance company in the Western Cape found out that there was a positive relationship between rewards, recognition and motivation. He concluded that organizations should review their current reward strategies in order to ensure higher employee motivation and increased job performance.

Gohari et al (2013) in a study of 100 employees who were randomly selected from two tourist companies in Malaysia examined the relationship between rewards and employee performance. The results of their study indicated that there was a positive relationship between rewards and employees performance. The study concluded that managers should consider employees' preferences of rewards before designing any reward management strategy so as to increase their motivation hence ensure that their organizations meet their objectives. Similarly, Joo (2010) in a study of 1000 employees from different industries in Korea investigated the impact of perceived organizational learning culture on organizational commitment. The study results indicated that organizational learning culture has a strong impact on organizational commitment. He concluded that managers and human resource professionals can enhance employees' organizational commitment by developing, improving and delivering the relevant human resource practices.

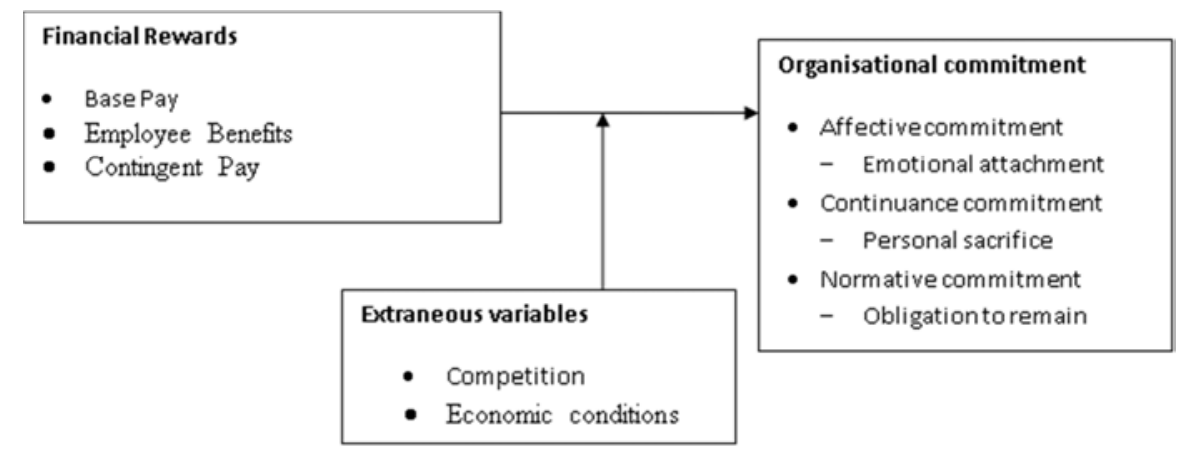

Figure 1. Conceptual Framework.

\section{Methodology}

The study adopted a correlation research design. According to Kothari (2008) correlation study tries to study a problem so as to explain the relationship between variables. The study was cross sectional survey study. Cross sectional survey is a type of observational study that involves the analysis of data collected from a population, or a representative subset. It involved collection of primary data at specific point in time. This is opposed to longitudinal study which involves collection of primary data over a long period of time.

The target population for the study comprised all permanent lecturers from the all the nine universities within the Nakuru County. The sample size of employees that were studied was determined by the use of the formula developed by Yamane (1967). According to Mugenda \& Mugenda (2009) $30 \%$ of the total population is considered as adequate sample size. The universities were picked on the basis of number of permanent lecturers. The study used simple random sampling to select respondents from each of the sampled universities. The formula used to calculate sample size is shown below.

$$
\mathrm{n}=\frac{N}{1+N(e)^{2}}
$$

Where: $\mathrm{N}=$ Population size take $\mathrm{n}=$ sample size

$\mathrm{e}=$ Margin error of the study set at $\pm 5 \%$

Table 1. Distribution of Teaching Staff per Institution.

\begin{tabular}{lll}
\hline No. & University & Population (N) \\
\hline 1 & Egerton University & 520 \\
2 & Jomo Kenyatta University (JKUAT) & 3 \\
3 & Kenyatta University & 10 \\
4 & Kabarak University & 75 \\
5 & University of Nairobi & 0 \\
6 & St. Pauls University & 4 \\
7 & Mount Kenya University & Not co-operative \\
8 & Presbyterian University & Not co-operative \\
9 & Kenya Methodist University & 13 \\
& TOTAL & 625 \\
\hline
\end{tabular}

Source: Human Resource office of each of the University (2015) 


$$
\begin{gathered}
n=\frac{625}{1+625(0.05) 2} \\
\frac{625}{1+0.155}=244 \\
=244 \text { teaching staff respondents }
\end{gathered}
$$

The sub-sample of size for each tertiary college was determined using the formula by Krecjie and Morgan (1970) as follows:

$$
\mathrm{s}=\frac{\mathrm{XS}}{P}
$$

Where;

$\mathrm{s}=$ Sub-sample size for each college

$\mathrm{X}=$ Population of employees in each college

$\mathrm{S}=$ Total sample size for the study

$\mathrm{P}=$ Total population of all the colleges based on job category of employees

Based on this formula, a total sample size of 245 respondents was used. Stratified Sampling was used get the respondents per institution from the target population. Information and the various departments and lecturers per department were provided by the human resource manager of the institution. The departments formed the strata and every nth number was provided with the questionnaire until the sample size was reached.

The study used self-administered questionnaires to collect primary data. The questionnaire was divided into three sections as follows: Section A: Employees background information Section B: Financial and non-financial rewards; Section C: Organizational commitment consisting of affective commitment, continuance commitment and normative commitment. Organizational commitment questions will be adopted from Meyer and Allen (1996).

Validity measures the ability of the research instruments to measure what it is intended to (Sekaran, 2010). To ensure face and content validity was achieved, thorough literature review was done in order to develop the questionnaire items so as to ensure that it tapped all the study variables. To enhance efficiency, the researcher sought assistance from research experts, lecturers and experienced graduates in order to help improve the validity of the instruments.

According to Mugenda and Mugenda (1999) reliability of an instrument is the degree of consistency with which it measures a variable. In this study, to ensure reliability of the instrument, the questionnaires were pilot tested amongst the lecturers of Laikipia University to ensure that the questionnaire items were understandable and free of ambiguity. Thereafter, the questionnaire was subjected to statistical testing using cronbach alpha. According to Saunders et al., (2007) an instrument with a reliability coefficient (alpha value) of more than 0.7 is assumed to be reliable. The reliability coefficient for the pilot test was above 0.70 which indicated that the research instruments were reliable, thus enabling the data collection to continue. The reliability coefficients for the main study are shown below in Table 2 .

Table 2. Reliability analysis for the study.

\begin{tabular}{llllll}
\hline S/No & Variables & No. of items & Cronbach Alpha Coefficient $(\boldsymbol{\alpha})$ & Items dropped & Final Cronbach Alpha Coefficient ( $\boldsymbol{\alpha})$ \\
\hline 1 & Financial rewards & 14 & 0.810 & None & 0.810 \\
3 & Affective commitment & 7 & 0.484 & Items 1 & 0.722 \\
4 & Continuance commitment & 6 & 0.779 & None & 0.779 \\
5 & Normative commitment & 5 & 0.845 & None & 0.845 \\
\hline
\end{tabular}

The data collected was coded, keyed into Statistical Package for Social Sciences (SPSS), organized and checked for any errors that may have occurred during data collection. The data was then be analyzed with the aid of the SPSS using both descriptive and inferential statistics. Descriptive statistics were used to analyze the mean scores and standard deviation for each of the factors. The results were interpreted and presented using graphs and tables. Inferential statistics was analyzed at the second stage of the data analysis to test the study hypotheses. The inferential statistics used to test the study hypotheses at 5\% significant level are as follows:

\section{Research Findings}

Correlation Analysis Findings

To determine the correlation between the aspects of employee reward management and organizational commitment, correlation analysis was conducted. The results of the analysis were as presented in table 3 below

Table 3. Pearson's Correlation Analysis exploring the relationship among rewards management practices and organizational commitment.

\begin{tabular}{llllll}
\hline & Affective Commitment & $\begin{array}{l}\text { Continuance } \\
\text { Commitment }\end{array}$ & $\begin{array}{l}\text { Normative } \\
\text { Commitment }\end{array}$ & $\begin{array}{l}\text { Organizational } \\
\text { Commitment }\end{array}$ \\
\hline \multirow{3}{*}{ Financial Rewards } & Pearson Correlation & $.344^{* *}$ & $.249^{* *}$ & $.246^{* *}$ & $.333^{* *}$ \\
& Sig. (2-tailed) & .000 & .008 & .009 & .000 \\
& N & 114 & 113 & 112 & 109 \\
\hline
\end{tabular}

**. Correlation is significant at the 0.01 level (2-tailed).

The study sought to establish whether financial rewards had significant effect on affective commitment of employees in universities in Nakuru County. The results in Table 3 showed that there was a moderate significant positive 
relationship between financial rewards and affective commitment $(r=0.344, p<0.001)$. This suggests that employees who were satisfied with their financial rewards had moderate levels of affective commitment. This is consistent with Scott (2010) study on the impact of financial rewards programs on employee emotional engagement to his or her work, which found that 42 percent of the respondents indicated that their organization's total rewards strategies had a positive effect on employee emotional engagement. This indicates that organizations which can link engagement to total rewards practices are more likely to affectively engage and motivate employees. Thus, the hypothesis that states that financial rewards do not have significant effect on affective commitment is rejected and the alternative that states that financial rewards have significant effect on affective commitment is accepted.

Secondly, the study sought to establish whether financial rewards had significant effect on normative commitment of employees in universities in Nakuru County. The results in Table 4 showed that there was a weak significant positive relationship between financial rewards and normative commitment $(\mathrm{r}=0.246, \mathrm{p}<0.01)$. This suggests that financial rewards positively influenced employees' loyalty and sense of obligation towards their university. This is consistent with findings by Melancon et al. (2010) which found that monetary rewards have a positive relationship with a normative commitment. Thus, the hypothesis that states that financial rewards do not have significant effect on normative commitment is rejected and the alternative that states that financial rewards have significant effect on normative commitment is accepted.

Lastly, the study sought to establish whether financial rewards had significant effect on continuance commitment of employees in universities in Nakuru County. The results in Table 3 showed that there was a weak significant positive relationship between financial rewards and continuance commitment $(\mathrm{r}=0.249, \mathrm{p}<0.01)$. This suggests that the perceived cost of leaving an organisation (continuance commitment) increased when employees were satisfied with their financial rewards. These findings are consistent with Gohari et al (2013) who found a positive relationship between rewards and employees continuance commitment among employees in tourist firms in Malaysia. Thus, the hypothesis that states that financial rewards do not have significant effect on continuance commitment is rejected and the alternative that states that financial rewards have significant effect on continuance commitment is accepted.

Regression analysis of Rewards management and affective commitment

Table 4. Regression analysis of rewards management and affective commitment.

\begin{tabular}{llllll}
\hline Model & R & R Square & Adjusted R Square & $\boldsymbol{F}$ (ANOVA) & Sig. \\
\hline 1 & $.500^{\mathrm{a}}$ & .250 & .236 & 17.504 & 0.000 \\
\hline
\end{tabular}

a. Predictors: (Constant), Financial Rewards
The model summary of the regression analysis in Table 4 shows that rewards management accounted for $25 \%$ of the variance in affective commitment among the respondents from universities in Nakuru County $(\mathrm{R}$ square $=0.250$ ). This shows that $75 \%$ of the variance in affective commitment was explained by factors not in the study

Regression analysis of rewards management and Continuance commitment

Table 5. Regression analysis of rewards management and Continuance commitment.

\begin{tabular}{llllll}
\hline Model & R & R Square & Adjusted R Square & $\boldsymbol{F}$ (ANOVA) & Sig. \\
\hline 1 & $.514^{\mathrm{a}}$ & .265 & .265 & 18.701 & 0.000 \\
\hline
\end{tabular}

a. Predictors: (Constant), Financial Rewards

The model summary of the regression analysis in Table 5 shows that rewards management accounted for $26.5 \%$ of the variance in continuance commitment among the respondents from universities in Nakuru County $(\mathrm{R}$ square $=0.265)$ and as such $73.5 \%$ of the variance in continuance commitment was explained by factors not in the study.

Regression analysis of rewards management and Normative commitment

Table 6. Regression analysis of rewards management and Normative commitment.

\begin{tabular}{llllll}
\hline Model & R & R Square & Adjusted R Square & $\boldsymbol{F}$ (ANOVA) & Sig. \\
\hline 1 & $.545^{\mathrm{a}}$ & .297 & .283 & 21.962 & 0.000 \\
\hline
\end{tabular}

a. Predictors: (Constant), Financial Rewards

Rewards management accounted for $29.7 \%$ of the variance in normative commitment among the respondents from universities in Nakuru County ( $\mathrm{R}$ square $=0.297$ ) as shown in the model summary of the regression analysis in Table 6. The other $70.3 \%$ of the variance in normative commitment was explained by factors that are not in the study

\section{Conclusions}

This study investigated the effect of rewards on multiaffective, normative and continuance commitment. The study found that financial rewards had significant effect on organisational commitment. The results of Pearsons Correlation analysis showed that financial rewards had significant positive effect on affective, normative and continuance commitment. This means that organisational commitment was high when employees received satisfactory financial rewards such as salary, bonuses, paid for trainings and seminars, transport, accommodation and medical allowances, annual pay increment and overtime pay. Financial reward management has insignificant effect on continuance commitment of employees in universities in Nakuru County. While organizations can use financial rewards to attract employees, financial rewards at times, may not be effective in retention of employees due to the level of perception the employees may have on them.

The findings from this study has shown that reward 
management practices contribute significantly to employees desire to remain or quit their jobs depending on how they are handled. In view of the study findings, it was therefore imperative for elaborate and specific recommendations to address the challenges facing the application of reward management practices as well as their effects on employee commitment in order to curb employee intention to turnover in Universities. The following recommendations are therefore suggested:

University management should sensitize their lecturers on the reward management criteria being applied in their respective institutions and guide them through their career paths. The reward management system being applied should be merit-based while hard work should be rewarded in order to encourage a committed teaching fraternity. Key performance indicators should be specified in order to ensure fairness in determining merit-based rewards.

Top university managers should also carry out salary reviews in order to develop a reward management structure that is externally competitive, internally fair and consistent with the current acceptable international rates. The reward structure should as much as possible be all rounded in order to take care of all concerned parties. In the reward structure, the financial and the non-financial rewards should match the performance achieved against set targets of each employee.

The top management in the Universities should also encourage employees' to participate in decision making and should implement employee suggestions. Decisions affecting employees should be communicated and be as fair as possible. There should also be channels available for employees to obtain clarity of decisions or additional information if they so require. Formulation and implementation of employee policies should be done in order to enhance consistency of decision making on lecturers and to guide their relationship with the top management. .

This study recommends that top university management must fully appreciate whether or not total rewards influence employee commitment. The study findings can be advantageous to human resource specialists who are required to recognize the role of total rewards management in organizations. Furthermore, the decision making organs of universities ought to consider implementing the findings of this study because it may assist them in determining the appropriateness of various elements of total rewards in enhancing organizational performance. Finally, the results of the study add knowledge to the existing literature and therefore act as a catalyst for future studies aimed at investigating issues related to total reward management and employees commitment.

The study was cross-sectional which means that the data was collected at one point in time. This means that the study was unable to capture the long-term effect of financial and non-financial rewards on organizational commitment. Future studies may carry out a similar study using longitudinal research design. Secondly, this study also focused on Universities in Nakuru County. A similar study should be carried out in universities in other regions of Kenya. Thirdly, a similar study should be carried out in non-educational institutions and also consider other determinants of employee commitment

\section{References}

[1] Bauer, T. N., \& Aiman-Smith, L. (1996). Career choices: The influences of ecological stance on recruiting. Journal of Business and Psychology, 10 (3), 445-458.

[2] Armstrong, M. (2012). Armstrong's Handbook of Human Resource Management Practice. New York, NY: Kogan Page Publishers.

[3] Armstrong, M., \& Baron, A. (2005). Managing Performance: Performance Management in Action. London, Chartered Institute of Personnel and Development.

[4] Armstrong, M., \& Murlis, H. (2007). Reward Management: A Handbook of Remuneration Strategy and Practice. London, Kogan Page Limited.

[5] Armstrong, M., Brown, D., \& Reilly, P. (2009). Increasing the Effectiveness of Reward Management. Brighton, Institute for Employment Studies.

[6] Beck, K., \& Wilson, C. (2000). Development of affective organizational commitment: A cross sequential examination of change with tenure. Journal of Vocational Behavior, 56 (1), 114-136.

[7] Bryson, A., Pendleton, A., \& Whitfield, K. (2013). The Changing Use of Contingent Pay at the Modern British Workplace. National Institute of Economic and Social Research, Discussion Paper No. 319.

[8] Chandramohan, A. (2008). Human Resource Management. New Delhi, APH Publishing Corporation.

[9] Chughtai, A., \& Zafar, S. (2006). Antecedents and Consequences of Organizational Commitment among Pakistani University Teachers. Applied H.R.M Research, 11 (1), 39-64.

[10] Coetzee, M. (2005). The Fairness of Affirmative Action: An Organizational Justice Perspective. Unpublished PHD Thesis, University of Pretoria.

[11] Condrey, S. (2010). Handbook of Human Resources Management. Oxon, John Wiley \& Sons.

[12] Cornellus, N. (2003. Human Resource Management: A Managerial Perspective., New York, NY: Cengage Learning.

[13] Crede, M., Chernyshenko, O. S., Stark, S., Dalal, R. S. and Bashshur, M. (2007). Job satisfaction as mediator: An assessment of job satisfaction's position within the nomological network. Journal of Occupational and Organizational Psychology, 80, 515-538

[14] Cropanzano, R., Rupp, D. E. and Byrne, Z. S. (2003). The Relationship of Emotional Exhaustion to Work Attitudes, Job Performance, and Organizational Citizenship Behaviors. Journal of Applied Psychology, 88 (1), p. 160-169

[15] Dalvi, M., \& Ebrahimi, H. (2013). Investigating the Effects of Reward on the Cooperation in the Sale and Marketing Department from Managers' Perspective (Isfahan Food industries Case Study). International Journal of Academic Research in Business and Social sciences, 3 (1), 144-153. 
[16] Danish, Q. D., \& Usman, A. (2010). Impact of Reward and Recognition on Job Satisfaction and Motivation: An Empirical Study from Pakistan. International Journal of Business and Management. 5 (2), 159-167.

[17] Danish, R., \& Usman, A. (2010). Impact of Reward and Recognition on Job Satisfaction and Motivation: An Empirical Study from Pakistan. International Journal of Business and Management, 5 (2), 159-167.

[18] Datta, P. (2012). An Applied Organizational Rewards Distribution System. Management Decision, 50 (3), 479-501.

[19] Denton, K. (2006). Empowerment through Employee Involvement and Participation. Empowerment in Organizations, 2 (2), 22-28.

[20] Dockel, A. (2003). The Effect of Retention Factors on Organizational Commitment: An Investigation of High Technology Employees. Master Thesis, University of Pretoria.

[21] Garacci, T., \& Kleiner, B. (2006). New Developments Concerning Employee Benefits and Pensions. Management Research News, 26 (3), 89-96.

[22] Gerald, S. (2006). Rewards and Job Commitment of Primary School Teachers in Mityana District. A Dissertation Submitted to Graduate Schoolin Partial Fulfillment of Requirements for the Award of the Degree of Masters of Arts in Educational Management of Makerere University.

[23] Gerald, S. (2011). Rewards and Job Commitment of Primary School Teachers in Mityana Diostrict, Uganda. Unpublished Masters of Educational Management Project, Makerere University.

[24] Gohari, P., Ahmadloo, A., Boroujeni, M., \& Hosscinipour, S. (2013. The Relationship between Rewards and Employee Performance. Interdisciplinary Journal of Contemporary Research in Business, 5 (3), 543-570.

[25] Haar, J. M. (2006). Challenge and hindrance stressors in New Zealand: exploring social exchange theory outcomes. International Journal of Human Resource Management, 17 (11), 1942-1950

[26] Hai, H. (2012). Factors Influencing Employee Commitment and Intention to Stay of Core Employees in Small-Medium Sized Company in Hochiminh City. Unpublished MBA Project, University of Economics Ho Chi Minh City.

[27] Harunavamwe, M. and Kanengoni, H. (2013). The Impact of Monetary and Non-Monetary Rewards on Motivation among Lower Level Employees in Selected Retail Shops. African Journal of Business Management. 7 (38), 3929-3935

[28] Hong, J., Yang, S., Chiou, E., Sun, F., \& Huang, T. (2005). Impact of Employee Benefits on Work Motivation and Productivity. The International Journal of Career Management, 7 (6), 10-14.

[29] Jackson, S., Schuler, R., \& Wermer, S. (2008). Managing Human Resources. New York, NY: Cengage Brain Learning.

[30] Jiang, Z., Xiao, Q., I, H., \& Xiao, L. (2009). Total Rewards Strategy: A Human Resources Management Strategy Going with the Trend of the Times. International Journal of Business and Management, 4 (11), 177-184.

[31] Joo, B. (2010). Organizational Commitment for knowledge Workers: The Roles of Perceived Organizational Learning Culture, Leader-Member Exchange Quality and Turnover intention. Human Resource Development Quarterly, 21 (1), 69-85.

[32] Kothari, C. (2008). Research Methodology: Methods and Techniques. New Delhi, New Age International Publishers.

[33] Lamastro, V. (1999). Commitment and Perceived Organizational Support. National Forum of Applied Educational Research Journal, 12 (3), 1-3.

[34] Latif, K. (2012). An Integrated Model of Training Effectiveness and Satisfaction with Employee Development Interventions. Industrial and Commercial Training, 44 (4), 211-222.

[35] Lee, C., Yang, C., \& Hambrick, M. (2012). The Relationship between Reward System and Organizational Commitment of Fitness Club Employees in Taiwan. North American Society for Sport Management Conference Paper, Seattle.

[36] Lee, W. (2010). The Relationship between Job Characteristics and Job Satisfaction toward Affective Commitment; The Case of Engineers in Sepakat Setia Perunding SDN BHD. Unpublished MBA Project, University Sains Malaysia.

[37] Macfie, B., \& Nufric, P. (2006). Applied Statistics for Public Policy. London, M.E Sharpe.

[38] Mahony, D., Klimshak, M., \& Morrell, D. (2012). The Portability of Career-Long Experience: Propensity to Trust as a Substitute for valuable Work Experience. Career Development International, 17 (7), 606-625.

[39] Manas, T., \& Graham, M. (2003). Creating a Total Rewards Strategy: A Toolkit for Designing. Washington, American Management Association.

[40] Martin, J. (2010). Concepts in Human Resource Management. London, Sage Publications Ltd.

[41] Meyer, J.P., \& Allen, N.J. (1996). Testing the 'Side-bet theory' of Organizational Commitment: Some Methodological Considerations. Journal of Applied Psychology, 69 (1)372378.

[42] Mollahosseini, A., Kahnouji, K., Shamsiyeh, A., \& Kahnouji, A. (2014). An Assessment of the Relationship between Managers' Power Resources and Employees Commitment of Governmental Organizations in Rafsanjan South Eastern Iran. International Journal of Academic Research in Economics and Management Science, 3 (1), 244-256.

[43] Mowday, R., Porter, L., \& Steers, R. (1982). Employeeorganization linkages: The psychology of commitment, absenteeism, and turnover. New York, NY: Academic Press.

[44] Muncherji, N., \& Dhar, U. (2011). Strategic Human Resources and Entrepreneurship. New Delhi, Excel Books.

[45] Narsee, N. (2012). Comparing the Impact of Monetary and Non-Monetary Reward Programs towards Employee and Organizational Motivation. Master Thesis, Gordon Institute of Business Science.

[46] Nda, M., \& Fard, R. (2013). The Impact of Employee Training and Development on Employee Productivity. Global Journal of Commerce \& Management Perspective, 2 (6), 91-93.

[47] Njanja, W., Maina, R., \& Njagi, K. (2013). Effect of Reward on Employee Performance: A Case of Kenya Power and Lighting Company Ltd, Nakuru, Kenya. International Journal of Business and Management, 8 (21), 41-49. 
[48] Nwosu, H., Chiamaka, J., \& Tochukwu, O. (2013). Job Characteristics as Predictors of Organizational Commitment among Private Sector Workers in Anambra State, Nigeria. International Journal of Asian Social Science, 3 (2), 482-491.

[49] Omolayo, B. and Owolabi, A. B. (2007). Monetary Reward: A Predictor of Employees' Commitment to Medium Scale Organizations in Nigeria. Bangladesh e-Journal of Sociology. Volume 4 (1), 42-49

[50] Pollitt, D. (2013). HSBC's Work-Experience Scheme is a Socially Responsible Winner: Pioneering Apprenticeship also Impress the Judges. Human Resource Management International Digest, 21 (5), 34-36.

[51] Porter, L.W., Steers, R.M., Mowday, R.T., \& Boulian, P.V. (1974). Organizational commitment, job satisfaction, and turnover among psychiatric technicians. Journal of Applied Psychology, 59 (2) 603-609.

[52] Price, A. (2011). Human Resource Management. New York, NY: Cengage Learning.

[53] Rhoades, L., Eisenberger, R., \& Armeli, S. (2001). Affective Commitment to the Organization: The Contribution of Perceived Organizational Support. Journal of Applied Psychology, 86 (5), 825-836.

[54] Roberts, R. (2010). The Relationship between Rewards, Recognition and Motivation at Insurance Company in the Western Cape. Unpublished MBA Project, University of the Western Cape.
[55] Rubin, A., \& Babbie, E. (2009). Essential Research Methods. Belmont, Cengage Learning

[56] Searle, M. S. (1990). Social Exchange Theory as a Framework for Understanding Ceasing Participation in Organized Leisure Activities. Sixth Canadian Congress on Leisure Research.

[57] Shields, J. (2007). Managing Employee Performance and Reward. Cambridge. Cambridge University Press.

[58] Singh, S. (2007). Compensation and Rewards Management. New Delhi, Excel Books.

[59] Sultana, A., Irum, S., Ahmed, K., \& Mehmood, N. (2012). Impact of Training on Employee Performance: A Study of Telecommunication Sector in Pakistan, Interdisplinary. Journal of Contemporary Research in Business, 4 (6), 646661 .

[60] Tsui, A., \& Lai, K. (2009). Professional Practices of Human Resource Management in Hong Kong. Hong Kong, Hong Kong University Press.

[61] Wilton, N. (2010). An Introduction to Human resource Management. London, Sage Publications.

[62] Wright, A. (2009). Reward Management in Context. London, CIPD Publishing.

[63] Yavuz, N. (2004). The Use of Non-Monetary Incentives as a Motivational Tool: A Survey Study in a Public Organization in Turkey. A Thesis Submitted To the Graduate School Of Social Sciences of Middle East Technical University 